\title{
TEKNIK CEKLIST SEBAGAI ASESMEN PERKEMBANGAN SOSIAL EMOSIONAL DI RA
}

\author{
Wardah Anggraini $^{1}$, Cahniyo Wijaya Kuswanto ${ }^{2}$ \\ ${ }^{1}$ Universitas Islam Negeri Sunan Kalijaga Yogyakarta, Indonesia \\ ${ }^{2}$ Universitas Islam Negeri Raden Intan Lampung, Indonesia \\ wardahanggraini@gmail.com
}

\begin{abstract}
This study aims to analyze the implementation of checklist techniques as an assessment to determine the emotional social development of early childhood. The method used in this research is descriptive qualitative by describing checklist techniques as an assessment used to determine social emotional development. This research uses data collection techniques including observation, interviews and documentation conducted at RA Insan Mulia Bambanglipuro, Bantul, Yogyakarta. Based on the results of research that has been carried out shows that RA Insan Mulia Bambanglipuro implement assessment techniques to assess the development of their students using checklist techniques, anecdotal notes and the work. including for assessing social emotional development using all three techniques, but one of the most prominent techniques to use is the checklist technique. This checklist technique is used by RA Insan Mulia in accordance with the 2015 Early Childhood Education Learning Assessment Guidelines, Ministry of Education and Culture Directorate General of Early Childhood Education and Community Education in 2015.
\end{abstract}

Keywords: Checklist Technique, Assessment, Emotional Social Development

\begin{abstract}
Abstrak
Penelitian ini bertujuan untuk menganalisis mengenai pelaksanaan teknik ceklis sebagai asesmen untuk mengetahui perkembangan sosial emosional anak usia dini. Metode yang digunakan dalam penelitian ini adalah deskriptif kualitatif dengan mendeskripsikan teknik ceklis sebagai asesmen yang digunakan untuk mengetahui perkembangan sosial emosional. Penelitian ini dengan teknik pengumpulan data diantaranya adalah observasi, wawancara dan dokumentasi yang dilaksanakan di RA Insan Mulia Bambanglipuro, Bantul, Yogyakarta. Berdasarkan hasil penelitian yang telah dilaksanakan menunjukan bahwa RA Insan Mulia Bambanglipuro melaksanakan teknik asesmen untuk menilai perkembangan anak didiknya dengan menggunakan teknik ceklis, catatan anekdot serta hasil karya. termasuk untuk penilaian perkembangan sosial emosional menggunakan ketiga teknik tersebut, namun salah satu teknik yang paling menonjol untuk digunakan adalah teknik ceklis. Teknik ceklis ini digunakan oleh RA Insan Mulia sesuai dengan Pedoman Penilaian Pembelajaran Pendidikan Anak Usia Dini, Kementerian Pendidikan dan Kebudayaan Direktorat Jenderal Pendidikan Anak Usia Dini dan Pendidikan Masyarakat Tahun 2015.
\end{abstract}

Kata Kunci: Teknik Ceklis, Asesmen, Perkembangan Sosial Emosional 


\section{PENDAHULUAN}

Pendidikan Anak Usia Dini (PAUD) adalah pendidikan yang bertujuan untuk memfasilitasi pertumbuhan dan perkembangan anak secara menyeluruh. Pelaksanaan pendidikan anak usia dini menekankan pada seluruh aspek perkembangan anak yaitu perkembangan nilai agama dan moral, kognitif, sosial emosional, bahasa, fisik motorik dan seni. Seluruh kegiatan yang dilaksanakan di lembaga pendidikan anak usia dini perlu dilaksanakan untuk mengembangkan potensi anak secara maksimal dan juga untuk menyiapkan anak menghadapi tahap pendidikan selanjutnya.(Suyadi \& Ulfah, 2013, p. 17).

Anak sebagai manusia yang merupakan makhluk yang monodualis adalah individu sekaligus mkhluk sosial, yang memiliki keterlibatan dengan orang lain yang mempunyai akal untuk dapat menyelesaikan tugas kesehariannya yang ditentukan oleh interaksinya dengan orang lain serta dapat memenuhi kebutuhan sehari-harinya. Ketidakmampuan seorang anak dalam bersosialissi dengan orang lain dipengaruhi oleh perkembangan aspek sosialnya yang terhambat. Aspek perkembangan sosial yang dialami oleh manusia selama hidupnya dimulai sejak manusia berada pada masa usia dini.

Aspek pekembangan sosial adalah proses interaksi yang dibangun antara individu dengan individu lain, atau seseorang dengan orang lain. Perkembangan tersebut terjalin yang dimulai dari orangtua, saudara, teman bermain dan masyarakat. Perkembangan sosial juga adalah proses belajar mengenal norma yang berada dimasyarakat dan peraturan dalam sebuah komunitas. Manusia selalu hidup dalam kelompok sehingga pkembangan sosialnya mutlak bagi setiap orang untuk dipelajari, beradaptasi serta menyesuaikan diri. Proses sosial emosional dapat muncul sebagai akibat adanya interaksi sosial yang dilakukan oleh individu, kelompok maupun masyarakat. Emosi tersebut dapat muncul sebagai sebuah reaksi fisiologis, perasaan dan perubahan perilaku yang nampak. Emosi yang terlihat pada anak usia dini adalah bentuk emosi yang real dan lebih kompleks karna mereka cenderung mengekspresikan emosinya dengan terbuka dan bebas.

Pendidik maupun calon pendidik dan pihak yang memperhatikan pendidikan anak membutuhkan pengetahuan mengenai perkembangan dan kemajuan anak didik. Karena setiap anak memiliki variasi individu dan mengalami tahap perkembangan dengan pencapaian yang variatif, maka perlu untuk mengetahui pencapaian perkembangan pada setiap tahapannya. Contohnya untuk mengetahui kemampuan anak prasekolah dalam perkembangan sosial emosionalnya dapat dilaksanakan dengan melihat cara anak bersosialisasi, berkomunikasi maupun berinteraksi dengan temannya saat bermain 
bersama. Dalam mengamati perilaku anak tersebut tentu akan ditemui anak yang mencapai tahap perkembangannya sesuai dengan standar namun ada pula anak yang berkembang lebih lambat atau bahkan lebih cepat dari anak yang lain (Suyadi, 2017, p. 66).

George Morisson berpendapat bahwa perkembangan sosial emosional yang positif akan memudahkan anak bergaul dengan teman sebayanya dan belajar dengan baik dan juga dalam aktifitas yang lainnya dilingkungan sosial. Saat anak memasuki Kelompok Bermain, PAUD dan TK, pada saat itu mereka keluar dari lingkungan keluarga dan memasuki dunia baru. Peristiwa tersebut merupakan situasi dari suasana emosional yang aman, ke kehidupan yang belum pernah dialami oleh anak pada saat mereka berada dilingkungan keluarga. Dalam duni baru tersebut, anak harus pandai menempatkan diri antara teman sebayanya, guru dan orang dewasa yang berada disekitarnya. (Nurjannah, 2017, p. 51).

Dalam melewati tugas perkembangan sosisl emosional tidak semua anak berhasil, sehingga terdapat berbagai kendala yang kemungkinan terjadi. Sebagai seorang pendidik sudah seharusnya memahami pekembangan sosial emosional anak sebagai bekal untuk memberikan bimbingan kepada anak agar mereka dapat mengembangkan kemampuan sosial emosionalnya secara optimal. Dapat diketahui bahwa proses suatu pembelajaran pada spek sosial emosional selain mendengarkan nasihat-nasihat yang diberikan guru ia juga dapat melihat bagimana seorang guru berkomunikasi dan ank dapat meniru apapun yang dilakukan oleh pendidik (guru). Anak anak dapat melihat bagaimana guru mengolah emosi dan mengkomunikasikan harapannya kepada peserta didik. Salah satu dampak dari ketidakmampuan anak usia dini dalam bersosialisasi adalah anak tersebut menglami gangguan perilaku antisosial. Pada kehidupan sehari-hari, perilaku antisosial pada anak usia dini tersebut tidak sulit ditemui, baik di lingkungan keluarga ataupun di lingkungan sekolah yaitu di Kelompok Bermain (KB) dan Taman Kanak-Kanak (TK).

Dalam dunia pendidikan asesmen di maknai sebagai sebuah proses secara sistematis yakni dengan pengumpulan, penganalisasian, penafsiran, serta pemberian sebuah keputusan tentang informasi yang dikumpulkan. Dari pengertian tersebut asesmen bukanlah suatu hasil malainkan sebuah proses yang dilakukan secara sistematsis. Proses tersebut dimulai dengan mengumpulkan informasi dan data kemudian menganalisis, menafsirkan dan yang terakhir adalah memberikan sebuah keputusan tantang data atau informasi yang dikumpulkan.

Asesmen tidak digunakan untuk mengukur keberhasilan sebuah program melainkan untuk mngetahui proses bagaimana perkembangan dan kemajuan belajar anak. Asesmen 
juga tidak dilakukan diakhir program akan tetapi dilakukan secara bertahap dan berkesinambungan sehingga perkembangan peserta didik dapat diketahui dengan mengamati tinak, tanduk anak pada saat bermain, menggambar ataupun dari kegiatan yang lainnya.

Teknik Asesmen cukup beragam, mulai dari asesment formal (tes standar) hingga informal. Dalam penididkan anak usia dini asesmen yang digunakan adalah asesmen informal yang lebih disarankan daripada penggunaan tes standar atau asesmen formal. Hal tersebut dilakukan kareana pola perkembangan anak masih sederhana, dan mereka banyak menghabiskan waktnya untuk bermain dengan teman sebayanya atau dengan orang dewasa.untuk mendeskripsikan perkembangan anak secara tepat dibutuhkan suasana secara alami dan tidak memaksa anak. Dengan adanya informasi tersebut selanjutnya bisa dijadikan sebuah dasr untuk membuat perencanaan dalam memberikan stimulus yang kompleks agar perkembangan anak optimal namun tetap dengan kebutuhan dan tahap perkembangan anak. Oleh karena itu asesment lebih teapat digunakan pada program pendidikan anak usia dini dari pada evaluasi. (Fridani, Wulan, \& Pujiastuti, 2016, p. 3).

Asesment dilaksanakan untuk mengetahui tingkat pencapaian kompetensi selama proses pembelajaran berlangsung dan seteah pembelajaran berlangsung guna memberikan umpan balik kepada anak didik untuk mengetahui kekuatan dan kelemahan dalam proses pencapaian kompetensi, memberikan umpan balik kepada guru untuk memperbaiki metode, pendekatan, kegiatan dan sumber belajar yang dilaksanakan dalam pemelajaran, juga sebagai bahan masukan bagi guru sebagai pihak dalam pembinaan selanjutnya terhadap anak didik serta menemukan kesulitan belajar yang dialami oleh anak untuk menilai potensi dan bakat yang bisa dikembangkan oleh anak.

Manfaat dari sebuah asesmen adalah mengetahui ketercapaian, kemampuan yang telah ditetapkan dalam sebuah kurikulum, untuk mencari keberhasilan dalam proses belajar mengajar, memproleh informasi kegiatan yang dilakukan sesuai dengan kebutuhan anak, memperoleh masukan tentang kelemahan dan kelebihan dari kegiatan belajar sehingga dapat digunakan untuk merencanakan kegiatan beajar berikutnya serta mempeoleh gambaran tentang pola dan gaya interaksi anak dengan teman sebayanya. Dalam melakukan penilaian perkembangan anak usia dini diperlukan instrumen untuk melihat tingkat perkembangan mereka. Instrument atau alat tersebut dapat diketahui dan diprediksi tentang perkembangan anak secara berkesinambungan, dan secara terus menerus sehingga 
pertumbuhan dan perkembangan sikap dan perilaku anak yang dipantau secara terus menerus. (Suyadi, 2017, pp. 70-71).

Untuk mengetahui bagaimana assesmen perkembangan anak di lembaga pendidikan anak usia dini sangat penting untuk dilaskanakan agar dapat dianalsisi untuk kemudian dapat dijadikan tinjauan bagi para pendidik maupun para pemerhati pendidikan, oleh karena itu dalam tulisan kali ini akan menjelaskan hasil penelitian mengenai asesmen perkembangan sosial emosional di RA Insan Mulia Bambanglipuro, Bantul, Yogyakarta.

\section{METODE PENELITIAN}

Metode yang digunakan dalam penelitian ini adalah penelitian kualitatif. Cresweel dalam Roselle berpendapat bahwa penelitian kualitatif lebih mengutamakan penggalian, penemuan, pembacaan, penjelasan, dan penyampaian makna atau simbol data yang terdapat pada data yang dikumpulkan (Roselle, 1996, p. 78). Kualitatif yang akan peneliti jabarkan adalah dengan menjelaskan teknik ceklis sebagai asesmen yang digunakan untuk menilai perkembangan sosial emosional anak yang dilakukan pendidik di RA Insan Mulia Bambanglipuro, Bantul, Yogyakarta. Responden dalam penelitian ini terdiri dari kepala sekolah dan guru di RA Insan Mulia Bambanglipuro. Pengumpulan data dalam penelitian ini menggunakan observasi, wwaancara dan dokumentasi. Sedangkan dalam menganalisis data dengan menggunakan teori miles dan hubberrman yakni reduksi data, penyajian data dan penarikan kesimpulan.

\section{HASIL PENELITIAN DAN PEMBAHASAN}

RA Insan Mulia Bambanglipuro menggunakan Assesmen perkembangan anak didik disekolah dengan tiga teknik yaitu dengan menggunakan Ceklist, anekdot dan Hasil karya.(Suminah, Siantayani, Paramitha, Ritayanti, \& Nugraha, 2018, p. 5). Assesmen di RA Insan Mulia Bambanglipuro juga dilaksanakan sesuai dengan prinsip-prinsip dalam melakukan penilaian yang dijelaskan dalam pedoman tersebut.

Teknik ceklis sebagai teknik asesmen dilaksanakan di RA Insan Mulia menggunakan 4 skala pengukuran sesuai ketentuan Pedoman Penilaian Pembelajaran Pendidikan Anak Usia Dini, 4 skala pengukuran tersebut yaitu dengan menggunakan singkatan BB (belum Berkembang), MB (mulai berkembang), BSH (berkembang sesuai harapan, dan BSH (berkembang sangat baik). Skala pengukuran ini diterapkan pada berkas-berkas assesmen yang diisi oleh guru pada saat pembelajaran telah selesai dilaksanakan. Pada berkas 
assesmen perkembangan peserta didik yang digunakan di RA Insan Mulia dengan ceklik per kelas yang meliputi 6 aspek perkembangan, kemudian di rincikan pada Kompetensi Dasar dan Indikator penilian dan format skala capaian perkembangan pada seluruh anak dalam satu kelas tertentu (misal kelas B). Tabel seperti pada gambar 1 dibawah ini merupakan assesmen ceklis per kelas, namun ceklis dalam hal ini bukan berupa tanda $(\sqrt{ })$ tetapi menggunakan 4 skala pengukuran status perkembangan anak.

Adapun pada teknik pencatatan anekdot, format yang digunakanpun telah sesuai dengan pedoman, hanya saja catatan anekdot yang ditulis masih seperti hanya formalitas dan kurang mendetail. Hal ini mungkin dikarenakan keterbatasan waktu yang dimiliki oleh guru dalam mengisi catatan anekdot secara mendetal untuk masing-masing anak. Dalam catatan anekdot hal hal yang perlu dicatat adalah nama anak, kegiatan bermain atau pengalaman belajar yang diikuti anak serta perilakunya, termasuk ucapaan yang disampaikan selama kegiatan belajar. Catatan anekdot tersebut dibuat dengan menuliskan apa yang, dibicarakan dan dilakukan anak secara akurat, objektif, sederhana, lengkap dan bermakna tanpa adanya pendsiran subjektif dari pendidik. Akurat (tepat), objektif (apa adanya, tanpa memberi label misalnya: cengeng, malas, nakal), spesifik (khusus/ tertentu), sederhana (tidak bertele-tele), dan catatan guru terkait dengan instrument dann indikator yang muncul dari perilaku anak.

Untuk catatan anekdot berpa jurnal kegiatan lebih baik disertai foto kegiatan anak. Saat guru sedang sibuk untuk memfasilitasi anak, dan saat yang bersamaan guru sempat menangkap aktivitas yang dilakukan anak, yang aktivitas tersebut mempunyai makna, setelah itu guru dapat mencoret-coret dengan kata-kata singkatan sebagai pengingat. Bisa juga menggunakan kamera yang mempermudah untuk merekam kegiatan anak berupa foto maupun video, selanjutnya setelah anak pulang, peristiwa yang sudah di abadikan ditulis lebih lengkap. Namun hal tersebut tidak dilakukan oleh guru di RA Insan Mulia, guru hanya memotret anak pada saat proses pembuatan hasil karya, karena foto tersebut dijadikan dokumentasi hasil karya mingguan anak.

Selain menggunakan teknik ceklis dan catatan anekdot, teknik lainnya adalah dengan menggunakan hasil karya. Hasil karya merupakan buah hasil dari pikiran anak yang dituangkan melalui sebuah bentuk karya yang nyata, karya tersebut dapat berupa pekerjaan tangan, karya seni atau tampilan anak, misalnya: lipatan, lukisan, kolase hasil guntingan, tulisan/ coretan, bangunan balok dah hasil prakarya lainnya. Pada saat hasil karya itu dibuat, guru menuliskan nama dan tangga hasil karya tersebut sebagai identitas. Pada 
umumnya hasil karya adalah sebuah contoh dari jenis prakarya yang menunjukkan perkembangan anak, kemampuan dan kemajuan anak, serta pencapaian anak selama berada dilingkungan sekolah. Bagi anak usia dini hasil karya seperti menggambar anak dengan anggota keluarga mencerminkan pemahaman mereka akan sebuah konsep tematik yangberkaitan dengan anggota keluarga. Hasil karya tersebut dimasukkan kedalam portofolio yang menjadi sarana penyimpanan karya-karya anak

Langkah penting untuk mengumpulkan penilaian perkembangan anak adalah dengan memilih kinerja yang baik dalam hal ini adalah perkembangan sosial emosionalnya. Data tersebut diperlukan untuk melihat sejauh mana perkembangan hasil karya yang dibuat oleh anak diwaktu yang sebelumya. Saat anak berproses menyelesaikan hasil karya tersebut guru berbincang-bincang dan menanyakan satu persatu anak tentang karya yang dibuatnya untuk melatih sosial emosionalnya termasuk bahasa ketika berinteraksi dengan guru. Kemudian guru menuliskan semua kata yang di obrolkan untuk menginformasikan sebuah hasil karya yang dibuatnya agar salah satu guru membuat interpretasi karya yang dibuat oleh anak. Hasil karya tersebut berupa kerajinan tangan, seni atau hasil karya yang lainnya yang dilakukan pada saat kegiatan berlangsung dan pada saat anak telah selesai menciptkan hasil karya tersebut. Hasil karya yang telah diciptakan jangan di dokumentasikan untuk dilaporkan kepada orangtua.

RA Insan Mulia menggunakan hasil karya untuk assesmen perkembangan peserta didiknya, namun penggunaan teknik hasil karya ini tidak dilaskanakan setipa hari/ harian. Assesmen hasil karya hanya dilaksanakan 1 minggu 1x. Berkas assesmen hasil karya mingguan ini menggunakan hasil karya yang di buat oleh anak berkdasarkan tema tertentu pada minggu tersebut. Biasanya setiap minggu di RA Insan Mulia, pembelajaran dilaksanakan dengan tematik tertentu dan dilaksanakan pembuatan hasil karya bagi para peserta didik yag kemudian hasil karya terebut dapat dilampirkan untuk assesmen. Pemberkasan hasil karya ini dilaksanakan dengan cara guru memotret anak didik beserta hasil karyanya, kemudia foto tersebut disusun dengan rapi dan kemudian di print. Sedangkan hasil karya anak yang telah di buat di sekolah biasanya diperbolehkan untuk di bawa pulang kerumah dan di tunjukan kepada orang tua/wali sebagai hasil karya anak belajar di sekolah.

Ketiga teknik tersebut stidak akan mampu digunakan oleh guru untuk menginterpretasikan perkembangan sosial emosional anak tanpa diiringi dengan melakukan observasi dan interview terhadap anak didik. Observasi perkembangan anak 
usia dini adalah bagian yang sangat penting dalam melihat pekembangan sosial emosional anak. Gardner memaknai observasi sebagai cara tebaik yang dilakukan untuk menilai kecerdasan jamak anak. Observasi juga dapat dgunakan untuk melihat bagaimana seorang anak memainkan permainan, bermain dengan benda di sekitarnya, melatih fisik motoriknya dengan bergerak dan menari serta mengatasi permasalahan dengan teman sebayanya.

Observasi yang dilakukanbisa menggunakan berbagai cara seperti kode observasi, observasi terfokus dan observasi insidental. Pada umumnya observasi menggunakan format tertentu seperti ceklist dengan tujuan tertentu. Misalnya perilaku anak yang nampak dan ditampilkan oleh anak tersebut. Teknik dalam observasi menggunakan cara pemberian kode, observasi yang terfokus dan observasi insidental. Umunya observasi terfokus menggunakan format-format tertentu berupa cheklist. Kemudian observasi insedental yaitu observasi yang tidak direncanakan yang bersumber dari kegiatan sehari-hari. Proses observasi ini dilakukan dengan mengamati ekspresi anak, gerak tubuhnya, reaksi anak ketika mendengar sesuatu dan ketika mengekspresikan sebuah kata-kata yang tersirat. Observasi jenis ini juga dapat digunakan ketika anak mulai belajar berbicara, berkata-kata dan pemahaman anak terhadap suatu peristiwa.dokuemntasi yang digunakan dalam observasi ini adalah pencatatan dan perekaman secara akurat dan lengkap.

Seperti hal nya observasi, hal yang penting digunakan untuk melakukan teknik asesmen perkembangan sosial emosional adalah interview yaitu wawacara atau berincangbincang dengan anak mengenai hal-hal yang berkaitan dengan aktivitasnya misalkan bermain, memilih permainan kesukaan anak, bermain dengan teman sebayanya, memilih pakaian dan makanan yang disukai serta perasaan anak pada saat belajar dan tentang karya karya yang dibuat oleh anak berkaita dengan perkembangan sosial emosionalnya.

Interview dilakukan oleh guru untu dapat mengetahui apakah anak dapat memahami dan menelaah sebuah konsep. Interview disini adalah berbincang-bincang langsung dengan narsumber yag dalam hal ini adalah anak usia dini. Interview ini sangat cocok digunakan untuk menggali sebuah informasi. Interview tersebut cocok digunakan untuk mengetahui perkembangan anak mulai mengenali akan sebuah emosi yng dialami, baik berupa sedih, senang, marah dan sebagainya. Ada beberapa interview yang dibisa digunakan yaitu intervie terstruktur dan tidak terstruktur serta diagostic. (Yin, 2012, p. 76).

Ketiga bentuk wawancara tersebut dapat dilakukan oleh guru dengan anak didik untuk melakukan asesmen perkembangan sosial emosionalnya kemudian dari hasil wawancara tersebut barulah guru dapat menilai dan menentukan sejauh mana pencapaian 
perkembangan sosial anak didik. Hasil penilaian ini kemudian di interpretasi menggunakan teknik ceklis dengan 4 skala pengukuran status perkembangan yang telah dijelaskan sebelumnya, sehingga penentuan penggunaan teknik ceklis dengan skala tersebut berdasarkan pada hasil observasi dan wawancara sebagaimana seharusnya asesmen autentik dilaksanakan di lembaga pendidikan anak usia dini, bukan hanya sebatas pencacatan formalitas atau subjektifitas guru dalam mengisi format asesmen dengan teknik ceklis tersebut.

\section{SIMPULAN DAN SARAN}

RA Insan Mulia melaksanakan asesmen perkembangan anak dengan menggunakan tiga teknik sesuai dengan Pedoman dalam Penilaian Pembelajaran Pendidikan Anak Usia Dini yaitu dengan menggunakan Ceklis, anekdot serta hasil karya. Penggunaan teknik asesmen diantara ketiga teknik tersebut yang paling dominan dan masif dilakukan adalah teknik ceklis, teknik ceklis ini dilaksanakan pada setiap kegiatan pembelajaran. Format pencatatan teknik ceklis ini tidak secara spesifik dibuat per-aspek perkembangan anak, namun ditulis dalam satu tabel yang mencakup seluruh aspek perkembangan anak, namun dalam konteks asesmen perkembangan sosial emosional, teknik ceklis ini dianggap cukup relevan untuk digunakan secara dominan dibandingkan dengan teknik catatan anekdot dan teknik hasil karya yang bahkan hanya digunakan 1x dalam 1 minggu untuk menginterpretasikan penilaian perkembangan anak karena teknik ceklis ini di susun pada tabel dengan 4 skala pengukuran status perkembangan anak berdasarkan hasil observasi dan interview guru dengan anak terkait dengan perkembangan sosial emosional anak.

Teknik ceklis sebagai asesmen perkembangan sosial emosional anak didik di RA Insan Mulia dilakukan dengan mengisi format ceklik per kelas sesuai dengan Pedoman Penilaian Pembelajaran Pendidikan Anak Usia yang meliputi 6 aspek perkembangan dan disesuaikan dengan Kompetensi Dasar dan Indikator pada tema-tema pembelajaran sesuai dengan rencana pembelajaran yang telah disusun per minggu oleh guru-guru.

Meskipun teknik ceklis hanya berupa format tabel dalam satu lembar setiap hari per kegiatan pembelajaran yang dilaksanakan dan digunakan untuk penilaian aspek perkembangan anak dengan catatan 4 skala tersebut, namun berdasarkan hasil wawancara dengan guru di RA Insan Mulia bahwa dalam realitanya hasil asesmen perkembangan anak dipahami oleh guru secara lebih mendalam dan disampaikan kepada pihak orangtua/ wali anak secara continue melalui buku penghubung dan juga berkas laporan semester, bahkan 
guru dapat memahami secara spesifik pada masing-masing anak mengenai perkembangan yang di alami oleh anak, begitupun dalam konteks perkembangan sosial emosional anak, karena guru mengamati perubahan yang dialami oleh anak dari interaksi yang dialami langsung oleh guru dengan anak setiap harinya dan juga dengan memperhatikan faktorfaktor lain yang mendukung ataupun menghambat perkembangan sosial emosional anak, sehingga dari asesmen yang telah dilaksanakan kemudian dapat dilakukan tindakan untuk mengoptimalkan perkembangan pada anak yang mengalami keterlambatan dalam mencapai standar perkembangan sosial emosionalnya dengan diberikan stimulus yang lebih, juga dengan memberikan apresiasi kepada anak-anak yang telah berhasil berkembang sangat baik.

Saran dalam penelitian ini untuk pengembangan selanjutnya agar teknik penilaian ceklist lebih mendalam dan akurat diperlukan kerjasama yang baik antar orangtua dan guru. Tidak hanya dalam aspek sosial emosional, akan tetapi ada penilaian terkait perkembangan anak usia dini yang lain seperti aspek kognitif, bahasa, fisik motorik, moral agama dan seni.

\section{DAFTAR PUSTAKA}

Fridani, L., Wulan, S., \& Pujiastuti, S. I. (2016). Evaluasi Perkembangan Anak Usia Dini (1st ed.). Banten: Universitas Terbuka.

Nurjannah. (2017). Mengembangkan Kecerdasan Sosial Emosional Anak Usia Dini Melalui Keteladanan. HISBAH: Jurnal Bimbingan Konseling Dan Dakwah Islam, 14(1), 50-61. https://doi.org/10.14421/HISBAH.2017.\%X.

Roselle, A. (1996). The case study method: A learning tool for practising librarians and information specialists. Library Review, 45(4), 30-38.

Suminah, E., Siantayani, Y., Paramitha, D., Ritayanti, U., \& Nugraha, A. (2018). Pedoman Penilaian Pembelajaran Pendidikan Anak Usia Dini. Jakarta: Direktorat Pembinaan Pendidikan Anak Usia Dini Direktorat Jenderal Pendidikan Anak Usia Dini dan Pendidikan Masyarakat Kementerian Pendidikan dan Kebudayaan.

Suyadi. (2017). Perencanaan dan Asesmen Perkembangan Pada Anak Usia Dini. Golden Age: Jurnal Ilmiah Tumbuh Kembang Anak Usia Dini, 1(1), 65-74.

Suyadi, \& Ulfah, M. (2013). Konsep dasar PAUD. Bandung: PT. Remaja Rosda Karya.

Yin, R. K. (2012). Studi Kasus Desain dan Metode. Jakarta: Grafindo Persada. 